\title{
IMPLEMENTASI SWOT PADA INSTITUSI PENDIDIKAN DALAM MENINGKATKAN ANGKA PARTISIPASI KASAR
}

\author{
Anfas 1 ) \\ Zainuddin2) \\ 1)Universitas Terbuka \\ 2)Universitas Khairun \\ e-mail: anfas_st_mm@ut.ac.id
}

\begin{abstract}
This study aims to measure the opportunities and challenges Institusion Universitas Terbuka of Regional office Ternate (UPBJJ-UT Ternate) through the expectations of high school students towards universities. Students' expectations of higher education are measured by the marketing mix of higher education services which include products, prices, places, promotions, people, process and physical evidence. This research is a qualitative descriptive study. The sources of information in this study were students in class XII in the city of Tidore Islands and West Halmahera Regency with a total sample of 461 students. Data collection techniques use interviews, observation and documentation. Data were analyzed using models from Milles and Michael Huberman with the stages of data collection, data reduction, data presentation, and conclusion drawing. The results of the study show that: 1) In the aspect of the product, students consider universities that have study programs / majors that are of interest to students; 2). In the price aspect, students consider universities that offer SPP fees affordable; 3). In the aspect of place, students are more expecting higher education that is close to the city center; 4). In the aspect of promotion, students prefer universities that conduct face-to-face promotions in their schools; 5). In the aspect of people, students expect universities that have lecturers / tutors with capable educational qualifications; 6). In the aspect of process, students expect universities that have easy new student registration programs; and 7). In the aspect of physical evidence, students expect higher education institutions with comfortable learning spaces.
\end{abstract}

Keywords: SWOT, Marketing Mix of Higher Education Services, Gross Enrollment rate

\begin{abstract}
ABSTRAK
Penelitian ini bertujuan untuk mengukur peluang dan tantangan Institusi Universitas Terbuka pada kantor regional Ternate (UPBJJ-UT Ternate) melalui ekspektasi siswa SLTA terhadap Perguruan Tinggi. Ekspektasi siswa terhadap perguruan tinggi diukur dengan bauran pemasaran jasa perguruan tinggi yang meliputi produk, harga, tempat, promosi, sumber daya manusia, aktivitas operasional dan sarana dan prasarana. Penelitian ini merupakan penelitian deskriptif kualitatif. Sumber informasi dalam penelitian ini adalah siswa kelas XII di Kota Tidore Kepulauan dan Kabupaten Halmahera Barat dengan total sampel sebanyak 461 Siswa. Teknik pengumpulan data menggunakan wawancara, observasi dan dokumentasi. Data dianalisis dengan menggunakan model dari Milles dan Michael Huberman dengan tahapan pengumpulan data, reduksi data, penyajian data, dan penarikan kesimpulan. Hasil penelitian menunjukkan bahwa: 1) Pada aspek produk, siswa lebih mempertimbangkan perguruan tinggi yang memiliki program studi/jurusan yang
\end{abstract}


diminati oleh siswa; 2). Pada aspek harga, siswa lebih mempertimbangkan perguruan tinggi yang menawarkan biaya SPP yang terjangkau; 3). Pada aspek tempat, siswa lebih mengharapkan perguruan tinggi yang dekat dengan pusat kota; 4). Pada aspek promosi, siswa lebih memilih perguruan tinggi yang melakukan promosi melalui tatap muka langsung di sekolah mereka; 5). Pada aspek sumber daya manusia, siswa lebih mengharapkan perguruan tinggi yang memiliki dosen/tutor dengan kualifikasi pendidikan yang kapabel; 6). Pada aspek aktivitas operasional, siswa lebih mengharapkan perguruan tinggi yang memiliki program pendaftaran mahasiswa baru yang mudah; dan 7). Pada aspek sarana dan prasarana, siswa lebih mengharapkan perguruan tinggi dengan ruang belajar yang nyaman.

Kata Kunci: SWOT, Bauran Pemasaran Jasa Pendidikan Tinggi, APK

Pendidikan merupakan modal penting bagi pembangunan Sumber Daya Manusia (SDM). Terlebih lagi di era otonomi daerah, ketersediaan SDM terdidik sangat menentukan kemampuan daerah untuk berdaya saing dengan daerah lainnya. Untuk itu, masyarakat harus diberikan kemudahan dalam mengakses pendidikan di berbagai jenjang pendidikan. Dengan adanya akses pendidikan yang mudah dijangkau, maka peluang masyarakat untuk terus melanjutkan pendidikannya ke jenjang yang lebih tinggi semakin terbuka luas, tanpa memandang status sosial dan ekonominya.

Undang-Undang Nomor 20 tahun 2003 tentang Sistem Pendidikan Nasional, membagi jalur pendidikan menjadi tiga, yakni pendidikan Formal, Non Formal dan Informal. Sedangkan dari jenjang pendidikannya, dibagi menjadi lima jenjang yaitu Pendidikan Anak Usia Dini (PAUD), Sekolah Dasar (SD), Sekolah Menengah Pertama (SMP), Sekolah Menengah Atas (SMA) dan Perguruan Tinggi (PT). Semakin tinggi daya jangkau masyarakat dalam mengakses pendidikan ke semua jenjang pendidikan, maka tentunya akan semakin tinggi pula nilai Angka Partisipasi Kasar (APK) pendidikan di daerah tersebut. Artinya bahwa Indeks Pembangunan Manusia (IPM) daerah tersebut bisa dikatakan baik, Bahkan oleh United Nations for development Program (UNDP) yang merupakan salah satu badan yang menangani pembangunan manusia di PBB, telah menetapkan Indeks Pembangunan Manusia (IPM) di tiap negara sebagai indikator penting untuk melakukan penilaian terhadap upaya pembangunan ekonomi suatu Negara (Arsyad: 2012; Suryarama, S, 2009).

Khusus untuk pendidikan tinggi angka partisipasi kasar (APK) tahun 2012 sebesar 28\% tahun 2013 naik menjadi 33\% dan tahun 2015 naik menjadi 33,66\%. Walaupun terjadi kenaikan, namun masih rendah dibandingkan dengan APK tingkat pendidikan lainnya. Rendahnya APK Pendidikan Tinggi di Indonesia tentunya menjadi pekerjaan rumah bersama bagi pemerintah pusat, pemerintah daerah dan masyarakat. Terutama di daerah-daerah kawasan timur Indonesia, sudah pasti APK Pendidikan Tingginya masih sangat rendah. Salah satunya adalah di Provinsi Maluku Utara, data BPS Maluku Utara tahun 2010, menunjukkan bahwa dari 109.120 penduduk Maluku Utara yang berusia 19-24 tahun sebanyak 5.855 (5,37\%) yang mampu melanjutkan pendidikannya hingga ke Perguruan Tinggi. Kemudian dari data Kemendikbud tahun 2013, menunjukkan bahwa dari 109.450 masyarakat Maluku Utara yang berusia 19-23 tahun hanya $29.368(30,45 \%)$ yang mampu melanjutkan ke Pendidikan Tinggi. Artinya bahwa masih ada 80.082 (69,55\%) penduduk usia 19-23 tahun yang belum mendapatkan kesempatan melanjutkan pendidikan ke perguruan tinggi.

Penelitian ini dimaksudkan untuk mengetahui tantangan dan peluang institusi pelayanan UPBJJ-UT Ternate melalui gambaran ekspektasi siswa atas perguruan tinggi yang nantinya akan menjadi tempat pendidikan selanjutnya setelah lulus sekolah. Instrumen yang digunakan dalam 
penelian ini adalah strategi bauran pemasaran pendidikan tinggi, yang terdiri dari Produk (product), harga (price), tempat (place), promosi (promotion), sumber daya manusia (people), aktivitas operasional (process) dan sarana prasarana (physical evidence) yang menunjang jalannya proses pembelajaran di Perguruan Tinggi.

Mengadopsi dari ilmu pemasaran mengenai ekspektasi konsumen yang merupakan informasi penting untuk digali oleh produsen agar dapat menyediakan layanan jasa/produk yang sesuai dengan keinginannya. Oleh sebab itu ekspektasi atau harapan konsumen selalu dikaitkan dengan tingkat kepuasan.

Menurut Gilbert (2003), elemen dari harapan pelanggan dapat dikelompokkan Tangible, Realibility, Responsiveness, Competence dan Emphaty. Merujuk pandangan tersebut, maka layanan institusi perguruan tinggi perlu memperhatikan ekspektasi atau harapan masyarakat yang erat kaitannya dengan competence perguruan tinggi berupa jaminan terhadap mutu pendidikan yang diselenggarakannya. Kemudian dari aspek bukti fisik (tangible), yakni berupa ketersediaan sarana prasana yang menunjang pendidikan para mahasiswanya. Responsiveness seperti kemudahan bagi mahasiswa dalam memperoleh sumber ilmu, baik dari dosen maupun dari sumber bacaan yang disediakan perguruan tinggi. Serta adanya Emphaty berupa kepedulian dari pihak Perguruan Tinggi terhadap kemampuan ekonomi mahasiswa, bahwa tidak semua masyarakat mampu secara ekonomi untuk mengenyam pendidikan tinggi (Priyati, R. Y, 2009). Khusus untuk aspek terakhir ini, tentunya telah mendapat perhatian dari Pemerintah yakni dengan mewajibkan perguruan tinggi untuk dapat menampung $20 \%$ dari total mahasiswa baru yang berasal dari kalangan masyarakat yang berekonomi tidak mampu.

Menurut Afiff (2008) pemasaran universitas atau pemasaran perguruan tinggi adalah suatu fungsi yang perlu dimiliki universitas dalam menciptakan, mengkomunikasikan dan menyampaikan nilai, dalam hal ini adalah informasi dan ilmu pengetahuan kepada mahasiswa dan masyarakat yang menjadi pasar sasaran. Setelah itu barulah dilakukan upaya dalam mengelola hubungan dengan mereka yang kesemuanya dapat menghasilkan manfaat bagi universitas dan para stakeholder-nya. Dengan demikian, maka positioning universitas dapat dilakukan melalui sejumlah bauran pemasaran jasa pendidikan tinggi, yang terdiri dari 7P, yaitu: Produk (product), harga (price), tempat (place), promosi (promotion), sumber daya manusia (people), aktivitas operasional (process) dan sarana prasarana (physical evidence) yang menunjang jalannya proses pembelajaran di Perguruan Tinggi.

\section{METODE PENELITIAN}

Jenis penelitian ini adalah penelitian deskriptif kualitatif dengan tujuan penelitian ini adalah mengungkap fakta, keadaan, fenomena, variabel dan keadaan yang terjadi saat penelitian berjalan dan menyuguhkan apa adanya. Populasi dalam penelitian ini adalah seluruh siswa kelas III di SLTA yang ada di Kabupaten Halmahera Barat dan Kota Tidore Kepulauan. Sedangkan sampel dalam penelitian ini dalah siswa kelas XII di Kabupaten Halmahera Barat dan Kota Tidore kepulauan dipilih secara acak yang berjumlah 461 siswa.

Metode analisis data menggunakan pendekatan Miles dan Huberman (2007) menyatakan bahwa aktivitas dalam analisis data pada penelitian kualitatif dilakukan secara interaktif dan berlangsung terus menerus sampai tuntas. Aktivitas analisis data sebagaimana yang diungkapkan tersebut meliputi tiga unsur yaitu reduksi data, penyajian data, penarikan kesimpulan. 


\section{HASIL DAN PEMBAHASAN}

Deskripsi profil responden berdasarkan jenis kelamin yaitu menguraikan atau menggambarkan jenis kelamin responden. Responden dalam penelitian ini adalah siswa-siswi kelas XII pada sekolah menengah atas di Kota Ternate, Kabupaten Halmahera Barat dan Tidore Kepulauan. Karakteristik responden berdasarkan jenis kelamin di masing-masing kota dan kabupaten tampak pada Tabel 1.

Tabel 1. Deskripsi Responden Berdasarkan Jenis Kelamin

\begin{tabular}{ccc}
\hline Keterangan & Jumlah Responden & Persentase (\%) \\
\hline - Laki- Laki & 167 & 36,23 \\
- Perempuan & 294 & 63,77 \\
\hline Jumlah & 461 & 100 \\
\hline
\end{tabular}

Sumber : Data Primer, 2018.

Berdasarkan Tabel 1 terlihat bahwa responden laki-laki berjumlah 167 orang atau 36,23\% dan responden perempuan berjumlah 294 orang atau 63,77\%. Hal ini berarti bahwa siswa SLTA yang di periode tahun depan akan masuk ke perguruan tinggi mayoritas berjenis kelamin perempuan.

\section{Distribusi tanggapan responden terhadap pertanyaan tentang Gambaran awal terkait perguruan tinggi}

Responden dalam hal ini diminta untuk menjawab pertanyaan-pertanyaan umum terkait gambaran awal tentang perguruan tinggi, yang dirangkum dalam Tabel 2.

Tabel 2. Tanggapan Responden Atas Gambaran Awal Perguruan Tinggi

\begin{tabular}{llrr}
\hline \multicolumn{1}{c}{ Pertanyaan } & Tanggapan Responden & Jumlah & Persentase (\%) \\
\hline Apakah setelah anda selesai SLTA, akan & - YA & 420 & 91,11 \\
melanjutkan ke perguruan tinggi? & - Tidak & 41 & 8,89 \\
\hline Apakah anda pernah mendengar kampus & - YA & 108 & 23,43 \\
yang bernama Universitas Terbuka? & - Tidak & 312 & 67,68 \\
\hline Jika anda pernah mendengar tentang & - Teman & 39 & 36,11 \\
kampus Universitas Terbuka, dari mana & - Guru & 16 & 14,81 \\
anda mendengarnya? & - Sosialisasi dan Promosi & 19 & 17,59 \\
& - Media Elektronik & 9 & 8,33 \\
& - Media Sosial & 25 & 23,15 \\
\hline Bagi anda yang berniat kuliah, apakah anda & - YA & 243 & 57,86 \\
telah memiliki kampus tujuan? & - Belum & 177 & 42,14 \\
\hline Kampus mana tujuan kuliah anda? & - Luar kota & 115 & 47,33 \\
& - Dalam kota: & 3 & 1,23 \\
& - Univ. Terbuka & 74 & 30,45 \\
& - Univ. Khairun & 14 & 5,76 \\
& - UMMU & 19 & 7,82 \\
& - IAIN & 10 & 4,12 \\
& - STKIP & 8 & 3,29 \\
\hline
\end{tabular}


Dari Tabel 2 mayoritas siswa menginginkan untuk dapat melanjutkan ke perguruan tinggi dengan jumlah sebesar 420 siswa atau $91,11 \%$ sedangkan sisanya sebesar 41 siswa atau 8,89\% memilih tidak melanjutkan pendidikan ke perguruan tinggi dengan alasan yang beragam, diantaranya akan fokus untuk mengikuti tes di TNI dan kepolisian, bagi yang lulusan SMK ingin langsung bekerja atau berwirausaha. Dari 420 siswa yang ingin melanjutkan pendidikan ke perguruan tinggi tersebut, hanya sebanyak 108 siswa atau $23,43 \%$ yang sudah pernah mendengar kampus UT, sedangkan sisanya sebanyak 312 siswa atau $67,68 \%$ belum pernah mendengar atau tidak mengetahui kampus Universitas Terbuka. Hal ini menunjukkan bahwa brand Universitas Terbuka belum kuat bahkan di daerah yang jaraknya tidak jauh dari UPBJJ-UT Ternate sendiri.

Hasil selanjutnya menunjukkan bahwa mayoritas siswa tersebut mengetahui Universitas Terbuka dari temannya yaitu sejumlah 36,11\%. Hal ini dikhawatirkan siswa tersebut mendapatkan informasi yang bias atau informasi yang tidak mewakili keadaan UT yang sebenarnya. Selanjutnya, sebanyak $57,86 \%$ siswa telah memiliki perguruan tinggi tujuan. Sedangkan sisanya sebesar 42,14\% belum memiliki rencana perguruan tinggi mana yang akan mereka tuju. Dari 420 Siswa yang telah memiliki perguruan tinggi tujuan sebanyak 47,33\% memiliki keinginan untuk kuliah ke luar kota Ternate seperti ke kampus Universitas Gajahmada Yogyakarta, Universitas Hasanuddin Makassar, Universitas Sam Ratulangi Manado, Universitas Pattimura Ambon dan lainnya. Sedangkan sisanya sebesar 42,14\% memilih untuk tetap kuliah di dalam Kota Ternate yaitu ke Universitas Khairun $30,45 \%$, Institut Agama Islam Negeri Ternate (IAIN) sebanyak 7,82\%, Universitas Muhammadiyah Maluku Utara (UMMU) sebesar 5,76\%, STKIP Kieraha sejumlah 4,12\%, UPBJJ-UT Ternate sebesar $1,23 \%$ dan lainnya sejumlah $3,29 \%$.

\section{Distribusi tanggapan responden terhadap pertanyaan tentang bauran pemasaran jasa perguruan tinggi}

Instrumen yang digunakan dalam penelitian ini yaitu bauran pemasaran pendidikan tinggi 7P, yaitu produk (product), harga (price), tempat (place), promosi (promotion), sumber daya manusia (people), aktivitas operasional (process) dan sarana prasarana (physical evidence). Untuk lebih jelasnya berikut ini akan dijelaskan hasil tanggapan responden terkait variabel-variabel dimaksud.

\section{Tanggapan responden terhadap variabel product}

Tabel 3. Hasil Pilihan Responden Terhadap Variabel Produk

\begin{tabular}{|c|c|c|}
\hline Indikator & Jumlah & Persentase (\%) \\
\hline Kurikulum & 72 & 17,14 \\
\hline Jurusan/Program Studi & 103 & 24,52 \\
\hline Magang & 76 & 18,10 \\
\hline $\mathrm{KKN}$ & 83 & 19,76 \\
\hline Akreditas & 86 & 20,48 \\
\hline Jumlah & 420 & 100 \\
\hline
\end{tabular}

Sumber: Data Primer, 2018

Dari Tabel 3 terlihat bahwa semua indikator variabel produk diperhitungkan siswa dalam memilih perguruan tinggi. Dari 420 responden yang memilih akan melanjutkan pendidikannya ke perguruan tinggi, jika perguruan tinggi dilihat dari aspek produknya, maka $24,52 \%$ akan memilih perguruan tinggi berdasarkan jurusannya, 20,48\% mempertimbangkan akreditasi perguruan tinggi, $19,76 \%$ siswa memilih perguruan tinggi yang memiliki program KKN dan sejenisnya, $18,10 \%$ pemilih 
mempertimbangkan program magang mahasiswa yang disediakan perguruan tinggi dan sisanya mempertimbangkan kurikulum dari perguruan tinggi. Berdasarkan tabel di atas, dapat disimpulkan bahwa pada aspek produk, siswa lebih mengutamakan perguruan tinggi yang memiliki program studi/jurusan yang diminati oleh siswa. Mayoritas siswa yang diterima pada sebuah perguruan tinggi akan tetap melanjutkan pendidikannya jika jurusan atau program studi yang mereka lulusi sesuai dengan minat mereka.

\section{Tanggapan responden terhadap variabel price}

Tabel 4. Hasil Pilihan Responden Terhadap Variabel Harga

\begin{tabular}{lrc}
\hline \multicolumn{1}{c}{ Indikator } & Jumlah & Persentase (\%) \\
\hline Biaya SPP Terjangkau & 180 & 42,86 \\
Biaya Ujian yang murah & 77 & 18,33 \\
Bebas Biaya Pendaftaran & 60 & 14,29 \\
Bebas Biaya Sumbangan & 21 & 5,00 \\
Biaya Buku Terjangkau & 82 & 19,52 \\
\hline \multicolumn{1}{c}{ Jumlah } & 420 & 100
\end{tabular}

Sumber : Data Primer, 2018

Dari Tabel 4 terlihat bahwa semua indikator variabel harga diperhitungkan siswa dalam memilih perguruan tinggi walaupun hasil pilihan siswa yang bervariasi, namun indikator biaya SPP terjangkau menjadi ekspektasi $42,86 \%$ siswa. Selain itu, berturur-turut 19,52\% siswa memilih biaya buku yang terjangkau, 18,33\% memilih biaya ujian yang murah, 14,29\% siswa memilih perguruan tinggi yang membebaskan biaya pendaftaran dan $5 \%$ memilih perguruan tinggi yang tidak mewajibkan biaya tambahan lainnya berupa sumbangan. Berdasarkan Tabel 4 dapat disimpulkan bahwa pada aspek harga, siswa lebih mempertimbangkan perguruan tinggi yang menawarkan biaya SPP yang terjangkau.

3. Tanggapan responden terhadap variabel place

Tabel 5. Hasil Pilihan Responden Terhadap Variabel Tempat

\begin{tabular}{lrc}
\hline \multicolumn{1}{c}{ Indikator } & Jumlah & Persentase (\%) \\
\hline Dekat dengan Pusat Kota & 105 & 25,00 \\
Dekat dengan Pusat Belanja & 72 & 17,14 \\
Dekat dengan Perguruan Tinggi Lainnya & 55 & 13,10 \\
Dekat dengan Pusat Perkantoran & 97 & 23,10 \\
Dekat dengan Pusat Tempat Tinggal & 91 & 21,67 \\
\hline \multicolumn{1}{c}{ Jumlah } & 420 & 100 \\
\hline
\end{tabular}

Sumber: Data Primer, 2018

Dari Tabel 5 terlihat bahwa semua indikator variabel tempat diperhitungkan siswa dalam memilih perguruan tinggi. Dari 420 responden yang memilih akan melanjutkan pendidikannya ke perguruan tinggi, jika perguruan tinggi dilihat dari aspek tempatnya, sebanyak $25 \%$ akan memilih perguruan tinggi yang dekat dengan pusat kota, 23,10\% siswa memilih perguruan tinggi yang dekat dengan pusat perkantoran, $21,67 \%$ siswa memilih perguruan tinggi yang dekat dengan tempat tinggalnya, $17,14 \%$ siswa memilih perguruan tinggi yang dekat dengan pusat perbelanjaan dan $13,10 \%$ siswa memilih perguruan tinggi yang dekat dengan perguruan tinggi lainnya. Berdasarkan 
tabel di atas, dapat disimpulkan bahwa pada aspek tempat, siswa lebih mengharapkan perguruan tinggi yang dekat dengan pusat kota.

4. Tanggapan responden terhadap variabel promotion Tabel 6. Hasil Pilihan Responden Terhadap Variabel Promosi

\begin{tabular}{lrc}
\hline \multicolumn{1}{c}{ Indikator } & Jumlah & Persentase (\%) \\
\hline Promosi melalui Surat Kabar/Media Cetak & 53 & 12,62 \\
Promosi melalui Radio/Media Elektronik & 40 & 9,52 \\
Promosi melalui Papan Reklame & 70 & 16,67 \\
Promosi melalui Tatap Muka di Sekolah & 169 & 40,24 \\
Promosi melalui Media Sosial & 88 & 20,95 \\
\hline \multicolumn{1}{c}{ Jumlah } & 420 & 100 \\
\hline
\end{tabular}

Sumber: Data Primer, 2018

Dari Tabel 6 terlihat bahwa semua indikator variabel tempat diperhitungkan siswa dalam memilih perguruan tinggi. Dari 420 responden yang memilih akan melanjutkan pendidikannya ke perguruan tinggi, jika perguruan tinggi dilihat dari aspek promosi, sebanyak 40,24\% atau mayoritas siswa memilih promosi perguruan tinggi dilakukan melalui tatap muka langsung di sekolah mereka, $20,95 \%$ siswa memilih promosi perguruan tinggi dilakukan melalui media sosial, 16,67\% siswa memilih promosi perguruan tinggi dilakukan melalui papan reklame. Sedangkan hanya sebagian kecil siswa yang memilih promosi perguruan tinggi melalui media cetak dan elektronik yaitu masingmasing hanya sebesar $12,62 \%$ dan 9,52\%. Berdasarkan Tabel 6, dapat disimpulkan bahwa pada aspek promosi, siswa lebih memilih perguruan tinggi yang melakukan promosi melalui tatap muka langsung di sekolah mereka.

\section{Tanggapan responden terhadap variabel people}

Tabel 7. Hasil Pilihan Responden Terhadap Variabel Sumber Daya Manusia

\begin{tabular}{lrc}
\hline \multicolumn{1}{c}{ Indikator } & Jumlah & Persentase (\%) \\
\hline Kualifikasi Dosen/Tutor & 122 & 29,05 \\
Profesionalitas Manajemen & 109 & 25,95 \\
Staf Tata Usaha yang aspiratif & 81 & 19,29 \\
Staf Biro Akademik yang ramah & 59 & 14,05 \\
Petugas Kebersihan yang rajin & 49 & 11,67 \\
\hline \multicolumn{1}{c}{ Jumlah } & 420 & 100 \\
\hline
\end{tabular}

Sumber: Data Primer, 2018

Dari Tabel 7 terlihat bahwa semua indikator variabel sumber daya manusia diperhitungkan siswa dalam memilih perguruan tinggi. Dari 420 responden yang memilih akan melanjutkan pendidikannya ke perguruan tinggi, jika perguruan tinggi dilihat dari aspek sumber daya manusia, sebanyak 29,05\% akan memilih perguruan tinggi dengan mempertimbangkan kualifikasi pendidikan dosen/tutor, 25,95\% siswa memilih perguruan tinggi yang memiliki manajemen yang profesional, $19,29 \%$ siswa memilih perguruan tinggi yang memiliki staf tata usaha yang aspiratif, 14,05\% siswa memilih perguruan tinggi yang memiliki staf biro akademik yang ramah dan 11,67\% siswa memilih perguruan tinggi yang memiliki petugas kebersihan yang rajin. Berdasarkan Tabel 7 dapat 
disimpulkan bahwa pada aspek sumber daya manusia, siswa lebih mengharapkan perguruan tinggi yang memiliki dosen/tutor dengan kualifikasi pendidikan yang kapabel.

\section{Tanggapan responden terhadap variabel process}

Tabel 8. Hasil Pilihan Responden Terhadap Variabel Aktivitas Operasional

\begin{tabular}{lrc}
\hline \multicolumn{1}{c}{ Indikator } & Jumlah & Persentase (\%) \\
\hline Penerimaan mahasiswa baru yang selektif & 105 & 25,00 \\
Pendaftaran mahasiswa baru yang mudah & 120 & 28,57 \\
Prosedur test yang objektif & 91 & 21,67 \\
Kuliah tatap muka di kelas & 75 & 17,86 \\
Kuliah fleksibel melalui online & 29 & 6,90 \\
\hline \multicolumn{1}{c}{ Jumlah } & 420 & 100 \\
\hline
\end{tabular}

Sumber: Data Primer, 2018

Dari Tabel 8 terlihat bahwa semua indikator variabel aktivitas operasional diperhitungkan siswa dalam memilih perguruan tinggi. Dari 420 responden yang memilih akan melanjutkan pendidikannya ke perguruan tinggi, jika perguruan tinggi dilihat dari aspek aktivitas operasionalnya, sebanyak $28,57 \%$ siswa akan memilih perguruan tinggi dengan prosedur pendaftaran mahasiswa baru yang mudah, $25 \%$ siswa memilih perguruan tinggi yang selektif dalam penerimaan mahasiswa baru, $21,67 \%$ siswa memilih perguruan tinggi yang memiliki prosedur test yang objektif, 17,86\% siswa memilih perguruan tinggi yang berfokus pada kuliah tatap muka di kelas dan hanya $6,90 \%$ siswa memilih perguruan tinggi yang menerapkan sistem kuliah online. Berdasarkan Tabel 8 dapat disimpulkan bahwa pada aspek aktivitas operasional, siswa lebih mengharapkan perguruan tinggi yang memiliki program pendaftaran mahasiswa baru yang mudah.

\section{Tanggapan responden terhadap variabel physical evidance}

Tabel 9. Hasil Pilihan Responden Terhadap Variabel Sarana dan Prasarana

\begin{tabular}{lrc}
\hline \multicolumn{1}{c}{ Indikator } & Jumlah & Persentase (\%) \\
\hline Gedung kuliah yang bagus & 97 & 23,10 \\
Ruang belajar yang nyaman & 108 & 25,71 \\
Tersedianya ruang ibadah & 102 & 24,29 \\
Akses Internet yang lancar & 82 & 19,52 \\
Fasilitas Laboratorium dan Kantin & 31 & 7,38 \\
\hline \multicolumn{1}{c}{ Jumlah } & 420 & 100 \\
\hline
\end{tabular}

Sumber: Data Primer, 2018

Dari Tabel 9 terlihat bahwa semua indikator variabel sarana dan prasarana diperhitungkan siswa dalam memilih perguruan tinggi. Hal ini tampak pada hasil pilihan siswa yang bervariasi. Dari 420 responden yang memilih akan melanjutkan pendidikannya ke perguruan tinggi, jika perguruan tinggi dilihat dari aspek sarana dan prasarananya, sebanyak $25,71 \%$ akan memilih perguruan tinggi yang memiliki ruang belajar yang nyaman, $24,29 \%$ siswa memilih perguruan tinggi yang memiliki sebuah ruang khusus untuk ibadah, $23,10 \%$ siswa memilih perguruan tinggi yang memiliki gedung kuliah yang bagus, 19,52\% siswa memilih perguruan tinggi yang memiliki akses internet yang lancar, dan hanya 7,38\% siswa yang memilih perguruan tinggi yang memiliki fasilitas laboratorium dan 
kantin. Berdasarkan Tabel 9 dapat disimpulkan bahwa pada aspek sarana dan prasarana, siswa lebih mengharapkan perguruan tinggi dengan ruang belajar yang nyaman.

Berdasarkan ekspektasi siswa dalam mengakses perguruan tinggi, Universitas terbuka UPBJJ-UT Ternate dirasa perlu menganalisa mengenai kekuatan dan kelemahan yang dilakukan melalui telaah terhadap kondisi internal perguruan tinggi, serta analisa mengenai peluang dan ancaman yang dihadapi perguruan tinggi melalui telaah terhadap kondisi eksternal perusahaan.

\section{A. Strenght (Kekuatan)}

Analisa kekuatan UT-UPBJJ Ternate dapat digambarkan sebagai berikut:

\section{Terbuka untuk semua usia dengan biaya pendidikan yang terjangkau}

Tidak dapat dipungkiri, biaya pendidikan merupakan salah satu hal yang dipertimbangkan oleh siswa ketika memilih untuk melanjutkan pendidikannya ke perguruan tinggi. Dari hasil penelitian pada 420 siswa yang berniat melanjutkan pendidikannya ke perguruan tinggi, sebanyak 292 siswa atau 69,52\% mempertimbangkan biaya pendidikan dalam memilih perguruan tinggi. Salah satu kekuatan Universitas Terbuka yang dituangkan dalam Rencana Strategis Bisnis (RSB) tahun 20162020 adalah keterjangkauan biaya pendidikan. UPBJJ-UT Ternate dapat menjadi solusi bagi mahasiswa yang ingin kuliah tanpa batasan usia dengan biaya terjangkau.

\section{Tanpa Tes Masuk}

Hasil penelitian menunjukkan bahwa pada aspek aktivitas operasional, siswa lebih mengharapkan perguruan tinggi yang memiliki program pendaftaran mahasiswa baru yang mudah. Terkait hal tersebut, layanan Universitas Terbuka tersedia di seluruh wilayah nusantara dan di luar negeri yang menawarkan proses penerimaan mahasiswa baru yang bukan hanya mudah namun juga tanpa tes masuk perguruan tinggi.

\section{Kampus UPBJJ-UT berada di pusat Kota}

Hasil penelitian menunjukkan bahwa pada aspek tempat, siswa lebih mengharapkan perguruan tinggi yang dekat dengan pusat kota. UPBJJ-UT Ternate merupakan perguruan tinggi yang tepat sesuai dengan ekspektasi siswa. UPBJJ-UT Ternate yang beralamat di jalan raya Mangga Dua Ternate, berada di pusat kota dekat dengan pusat perbelanjaan, areal perkantoran dan perguruan tinggi lain.

\section{Prasarana yang berkualitas}

Siswa yang menjadi responden penelitian, menginginkan perguruan tinggi yang memiliki ruang belajar yang nyaman. UPBJJ-UT Ternate merupakan jawaban dari ekspektasi siswa tersebut. UPBJJ-UT Ternate telah memiliki ruang kelas yang nyaman dilengkapi dengan fasilitas AC, infokus dan whiteboard, akses internet yang cepat, tersedianya ruang ibadah dan perpustakaan, dan dekat dengan beberapa rumah makan dengan biaya terjangkau.

\section{B. Weakness (Kelemahan)}

Analisa kelemahan UT-UPBJJ Ternate dapat digambarkan sebagai berikut:

\section{Sumber Daya Manusia.}

Salah satu kelemahan UPBJJ-UT Ternate adalah kurangnya sumber daya manusia utamanya Dosen yang akan mengelolah layanan bantuan belajar bagi mahasiswa. Dari hasil penelitian, pada aspek sumber daya manusia, siswa mengharapkan perguruan tinggi yang menyediakan dosen/tutor yang qualified. Kelemahan ini telah diatasi oleh UPBJJ-UT Ternate dengan 
memanfaatkan sumberdaya setempat sebagai tutor di UPBJJ-UT Ternate seperti dari Unkhair, IAIN, UMMU, STKIP dan tenaga profesional lainnya.

\section{Brand dan Reputasi UT belum kuat}

Salah satu keunggulan Universitas Terbuka yang dituangkan dalam rencana strategis bisnis (RSB) yaitu sistem terbuka dan jarak jauh, artinya terbuka bagi seluruh lulusan SLTA sederajat tanpa membatasi tahun ijazah dan usia serta menjangkau seluruh wilayah nusantara. Namun kenyataanya, sebanyak 67,68\% menyatakan bahwa mereka belum/tidak mengetahui tentang Universitas Terbuka. Padahal domisili responden dalam penelitian ini hanya dilakukan di daerah kepulauan yang jaraknya paling dekat dengan kantor UPBJJ-UT Ternate. Belum dilakukan di daerah kepulauan terjauh. Lebih lanjut, dari total responden yang sudah mengenal UT, hanya 1,23\% yang memilih Universitas Terbuka sebagai perguruan tinggi tujuannya. Hal ini berarti bahwa Universitas Terbuka belum memiliki Brand dan Reputasi yang kuat di masyarakat.

\section{Pokjar di daerah belum beroperasi maksimal}

Sebagaimana rencana universitas terbuka untuk menjangkau wilayah di seluruh nusantara, maka Pokjar yang dibentuk di daerah-daerah harus menjadi ujung tombak untuk mempromosikan universitas terbuka di daerah tersebut, Hal ini yang tampaknya belum berjalan maksimal. Misalnya di daerah Halmahera Barat, UPBJJ-UT Ternate telah memiliki Pokjar di Halmahera Barat. Namun dari 299 siswa yang menjadi responden, diantaranya 264 siswa yang berniat melanjutkan pendidikannya ke perguruan tinggi. Dari 264 siswa tersebut, hanya 53 siswa atau 17,73\% yang telah mengenal Universitas Terbuka (UT). Demikan juga halnya dengan Kota Tidore Kepulauan, dari 162 siswa yang menjadi responden, diantaranya 156 siswa yang berniat melanjutkan pendidikannya ke perguruan tinggi. Dari 156 siswa tersebut, 55 siswa atau 33,95\% yang telah mengenal Universitas Terbuka (UT). Hal ini mengindikasikan bahwa Pokjar UT di daerah Halmahera Barat dan Kota Tidore Kepulauan belum beroperasi maksimal dalam mempromosikan Universitas Terbuka.

\section{Minimnya Sosialisasi dan Promosi melalui tatap muka}

Pada aspek promosi, sebanyak 40,24\% siswa memiliki ekspektasi terhadap perguruan tinggi untuk dapat mempromosikan perguruan tinggi melalui tatap muka langsung di sekolah. Kenyataannya, dari hasil tanggapan siswa, hanya 17,59\% siswa yang mengetahui Universitas Terbuka yang mendaptakan informasi UT dari sosialisasi dan promosi di sekolah. Mayoritasnya mendapatkan informasi UT melalui teman dan media sosial.

\section{Opportunity (Peluang)}

Analisa peluang UT-UPBJJ Ternate dapat digambarkan sebagai berikut:

\section{Masih banyaknya siswa yang belum menentukan perguruan tinggi tujuan}

Berdasarkan Tabel 2 terlihat bahwa dari 420 siswa yang berniat untuk melanjutkan pendidikan di perguruan tinggi, sebanyak 177 siswa atau 42,14\% yang belum menentukan pilihan perguruan tinggi mana yang akan mereka tuju. Hal ini menjadi kesempatan UPBJJ-UT Ternate untuk memperkenalkan, mempromosikan dan menawarkan program kuliah di kampus UPBJJ-UT. Sosialisasi dan promosi dirasa perlu dilakukan untuk memastikan UT sebagai salah satu perguruan tinggi yang menjadi tujuan siswa nantinya. Berbagai macam pilihan promosi dapat dilakukan namun diutamakan promosi melalui tatap muka langsung di sekolah, promosi melalui papan reklame dan melalui media sosial.

\section{Ketersediaan Beasiswa dari berbagai sumber khususnya CSR}

Berdasarkan rencana strategis bisnis universitas terbuka, total bidikmisi nasional lebih dari 75.000 orang per tahun. Selain itu kewajiban alokasi dana CSR bagi perusahaan sebesar $5 \%$ dari 
laba bersih per tahun. Hal ini dapat menjadi bahan promosi bagi Universitas Terbuka khususnya UPBJJ-UT Ternate kepada siswa-siswa baik yang sudah memiliki pilihan perguruan tinggi utamanya bagi mereka yang belum memiliki perguruan tinggi tujuan.

\section{Threat (Ancaman)}

Analisa ancaman UT-UPBJJ Ternate dapat digambarkan sebagai berikut:

\section{Meningkatnya Persaingan perguruan tinggi di Maluku Utara}

Dewasa ini, meningkatnya lulusan dari SLTA diikuti dengan meningkatnya animo siswa untuk kuliah di luar daerah. Hal ini terbukti dari hasil penelitian yang menunjukkan bahwa $47,33 \%$ responden penelitian memilih untuk melanjutkan pendidikan ke perguruan tinggi di luar daerah Maluku Utara. Selain itu semakin meningkatnya jumlah perguruan tinggi di Maluku Utara dapat menjadi ancaman UPBJJ-UT Ternate dalam merekrut mahasiswa baru. UPBJJ-UT Ternate diharapkan mampu mengeksplorasi segala kekuatan dan memanfaatkan peluang untuk dapat bersaing dengan perguruan tinggi lainnya dalam meningkatkan jumlah mahasiswa.

\section{Kebijakan Penyelenggaraan PJJ Oleh Perguruan Tinggi Lain}

Ancaman jangka panjang yang dikhawatirkan dapat mengganggu eksistensi Universitas Terbuka khususnya UPBJJ-UT Ternate adalah dengan diberlakukannya sistem pendidikan program jarak jauh oleh perguruan tinggi lainnya yang selama ini hal tersebut identik dengan Universitas Terbuka.

\section{PENUTUP}

Hasil penelitian terkait ekspektasi siswa SLTA dalam mengakses perguruan tinggi yang dilakukan di kabupaten Halmahera Barat dan Kota Tidore Kepulauan memperlihatkan temuan berbeda pada tiap aspeknya. Pada aspek produk dalam bauran pemasaran jasa pendidikan tinggi, siswa lebih mempertimbangkan perguruan tinggi yang memiliki program studi/jurusan yang diminati oleh siswa. Mayoritas siswa yang diterima pada sebuah perguruan tinggi akan tetap melanjutkan pendidikannya jika jurusan atau program studi yang mereka lulusi sesuai dengan minat mereka. Pada aspek harga dalam bauran pemasaran jasa pendidikan tinggi, siswa lebih mempertimbangkan perguruan tinggi yang menawarkan biaya SPP yang terjangkau. Pada aspek tempat dalam bauran pemasaran jasa pendidikan tinggi, siswa lebih mengharapkan perguruan tinggi yang dekat dengan pusat kota. Pada aspek promosi dalam bauran pemasaran jasa pendidikan tinggi, siswa lebih memilih perguruan tinggi yang melakukan promosi melalui tatap muka langsung di sekolah mereka. Pada aspek sumber daya manusia dalam bauran pemasaran jasa pendidikan tinggi, siswa lebih mengharapkan perguruan tinggi yang memiliki dosen/tutor dengan kualifikasi pendidikan yang kapabel. Pada aspek aktivitas operasional dalam bauran pemasaran jasa pendidikan tinggi, siswa lebih mengharapkan perguruan tinggi yang memiliki program pendaftaran mahasiswa baru yang mudah. Pada aspek sarana dan prasarana dalam bauran pemasaran jasa pendidikan tinggi, siswa lebih mengharapkan perguruan tinggi dengan ruang belajar yang nyaman.

\section{REFERENSI}

Afiff, Faisal. (2008). http://faisal-afiff.blogspot.com/2008/06/pemasaran-universitas-there-is-onlyone.html. Diunduh tangal 12 Februari 2015.

Arsyad, Lincolin. (2012). Ekonomi Pembangunan. Tanggerang: Percetakan Universitas Terbuka. Gilbert, David. (2003). Retail Marketing Management (2nd ed.). England: Prentice-Hall. 
Miles, Mattew B \& A. Michael Huberman. (2007). Analisis Data Kualitatif. Buku sumber tentang metode- metode baru. Jakarta: Universitas Indonesia. Press.

Priyati, R. Y. (2009). Hiv Prevalence And Socio-Economic Status In Sub-Saharan Africa. Jurnal Organisasi Dan Manajemen, 5(2), 73-81.

Suryarama, S. (2009). Peran Yayasan Dalam Pengelolaan Bidang Pendidikan Pada Perguruan Tinggi Swasta. Jurnal Organisasi Dan Manajemen, 5(1), 55-62.

Undang-Undang Nomor 20 Tahun 2003 Tentang Sistem Pendidikan Nasional, Jakarta: Depdiknas. Departemen Pendidikan Nasional, 2005.

Universitas Terbuka. (2018). Rencana Strategi Bisnis Universitas Terbuka Tahun 2016-2020 Edisi Revisi. 